\title{
Population structure of Comesoma arenae Gerlach (Nematoda, Comesomatidae) in a Brazilian tropical tidalflat, Rio de Janeiro, Brazil
}

\author{
André Morgado Esteves ${ }^{1,2}$, Tatiana Fabricio Maria ${ }^{1} \&$ Adriane Pereira Wandeness ${ }^{2}$ \\ ${ }^{1}$ Departamento de Zoologia, Instituto de Biologia, Universidade Estadual do Rio de Janeiro. Rua São Francisco Xavier 524, \\ 20550-900 Rio de Janeiro, Brasil.E-mail: aesteves@uerj.br \\ ${ }^{2}$ Departamento de Zoologia, Instituto de Biologia, Universidade Federal do Rio de Janeiro. Ilha do Fundão, 21941-570 Rio \\ de Janeiro, Brasil.
}

\begin{abstract}
The objective is to describe the population structure of Comesoma arenae Gerlach, 1956 during a oneyear period. The area studied, Coroa Grande, is located in Sepetiba Bay, State of Rio de Janeiro, Brazil. Sampling was carried out monthly, from May 1998 through April 1999. Most individuals in the population were adults, of which non-ovigerous females were the most abundant. The species showed its highest population densities during the colder months.

KEY WORDS. Marine nematodes, meiofauna.
\end{abstract}

RESUMO. O objetivo é descrever a estrutura populacional de Comesoma arenae Gerlach, 1956 durante um período anual. Coroa Grande, a área estudada, localiza-se na Baía de Sepetiba, Estado do Rio de Janeiro, Brasil. As coletas foram realizadas, mensalmente, de maio de 1998 a abril de 1999. A maioria da população foi representada pelos adultos, dos quais as fêmeas não-ovígeras foram a categoria mais abundante. A espécie mostrou as maiores densidades populacionais durante os meses mais frios.

PALAVRAS CHAVE. Meiofauna, nematóides marinhos.

Nematodes are the most abundant group of animals in the entire biosphere and may be free-living or parasites (MALAKHOV 1994). In the marine environment, they are the most abundant metazoans in the sediments (HeIP et al. 1982). Generally these animals pass through $1 \mathrm{~mm}$-mesh nets, and because they live between the sediment particles, have received little attention, except for taxonomic works (Nicholas \& Hodda 1999).

Comesoma arenae Gerlach, 1956 is a species of Nematoda first described from the Brazilian coast. Later, MurpHy (1964) recorded it from the Australian coast. However, there are no investigations of its biology and ecology from any region where it occurs. C. arenae was the most abundant member of the community in the tidalflat sediments at Coroa Grande, Rio de Janeiro. The objective of this investigation was to describe its population structure during one-year period.

\section{MATERIAL AND METHODS}

The area studied, Coroa Grande, is located in Sepetiba Bay (22 $\left.55^{\prime} 00^{\prime \prime} \mathrm{S}, 43^{\circ} 05^{\prime} 30^{\prime \prime} \mathrm{W}\right)$, Rio de Janeiro, Brazil.

Sampling was carried out monthly, from May 1998 through April 1999. Two fixed transects (200 m apart) were established from the higher limit of the subtidal zone to the supralittoral. At each transect, four equally spaced sampling strata parallel to the water line were marked according to a systematic design with stratification. At each stratum, three replicate cores of $1 \mathrm{~cm}^{2}$ (systematically allocated $3 \mathrm{~m}$ apart) were taken to a depth of $5 \mathrm{~cm}$.

The sediment samples were treated with the sugar-flotation method (Esteves \& SiLva 1998), using nets with mesh sizes of $500 \mu \mathrm{m}$ (upper limit) and $50 \mu \mathrm{m}$ (lower limit). For identification, slide mounts of nematodes were prepared according to the procedures described by PlatT \& WARWICK (1983) and RIEMANN (1988). The individuals of $C$. arenae were identified as males, non-ovigerous females, ovigerous females, or juveniles. The data were expressed as the number of individuals per 10 $\mathrm{cm}^{2}$. Pearson's correlation test (ZAR 1996) was applied to test for significant relationships between the total density and sediment temperature. The chi-square test was applied to test the significance of the male/female ratio during the sampling period.

\section{RESULTS AND DISCUSSION}

Sediment temperatures varied according to the season, being lower in May through November 1998 and higher in December 1998 through April 1999. The highest temperature $\left(33^{\circ} \mathrm{C}\right)$ was recorded in January 1999 , and the lowest $\left(20.5^{\circ} \mathrm{C}\right)$ in June 1998.

Revista Brasileira de Zoologia 21 (4): 775-777, dezembro 2004 
Most of the population individuals were adults, of which non-ovigerous females were the most abundant (Tab. I). The relationship between the total densities of the species and the temperature was negative and statistically significant (Fig. 1). The male/female ratio did not vary significantly during the sampling period $\left(\chi^{2}=1.96, p<0.05\right)$.

The results showed that the higher densities of $C$. arenae occurred in the colder months (Fig. 2). The densities of ovigerous females showed the same pattern of population, i. e., as the temperature increased the number of ovigerous females decreased (Fig. 2). Along (1990) expected that this would be a common behavior for species which are deposit-feeders and predators/omnivores, since these show greater population growth in autumn and winter (lower temperatures), because of the increased rates of detritus deposition in the environment at those times. However, this argument is not applicable to the study area, because it is highly degraded, with a large and constant organic input from domestic sewage year-round (AmAdo-Filho et al. 1999). In the same study area, the nematode species Oncholaimus cobbi (Kreis, 1932) showed an inverse pattern, i.e., its higher densities occurred during the warmer months (Esteves et al. 2003). This behavior is contrary to the suggestion of ALONGI (1990), because this species is a predator/ omnivore.
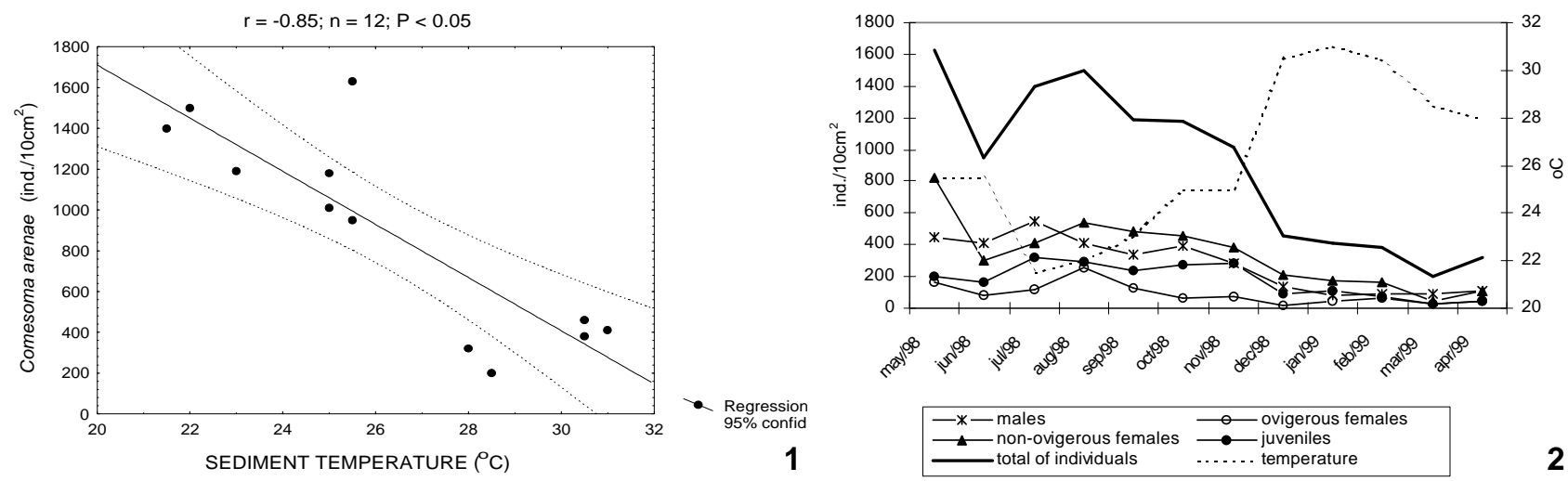

Figures 1-2. (1) Correlation between total density of Comesoma arenae and temperature during the sampling period; (2) temperature and total densities of Comesoma arenae during the sampling period.

Table I. Density (ind./10 $\mathrm{cm}^{2}$ ) during the sampling period.

\begin{tabular}{|c|c|c|c|c|c|}
\hline Months & Males & Ovigerous females & Non-ovigerous females & Juveniles & Total of individuals \\
\hline May/1998 & 450 & 160 & 820 & 200 & 1,630 \\
\hline June/1998 & 410 & 80 & 300 & 160 & 950 \\
\hline July/1998 & 550 & 120 & 410 & 320 & 1,400 \\
\hline August/1998 & 410 & 260 & 540 & 290 & 1,500 \\
\hline September/1998 & 340 & 130 & 480 & 240 & 1,190 \\
\hline October/ 1998 & 390 & 60 & 460 & 270 & 1,180 \\
\hline November/1998 & 280 & 70 & 380 & 280 & 1,010 \\
\hline December/1998 & 140 & 20 & 210 & 90 & 460 \\
\hline January/1999 & 80 & 50 & 170 & 110 & 410 \\
\hline February/1999 & 90 & 60 & 160 & 70 & 380 \\
\hline March/1999 & 90 & 30 & 50 & 30 & 200 \\
\hline April/1999 & 110 & 50 & 110 & 50 & 320 \\
\hline Total & 3,340 & 1,090 & 4,090 & 2,110 & 10,630 \\
\hline$\%$ & 31.42 & 10.25 & 38.48 & 19.85 & \\
\hline
\end{tabular}

Revista Brasileira de Zoologia 21(4): 775-777, dezembro 2004 
Therefore, food shortage is probably not occurring and other environmental factors may better explain the observed differences in the population structure of the two species. In this case, temperature may be the best explanation for this behavior. The influence of temperature on the life cycles of marine nematode species has been demonstrated previously by many workers (M OENS \& VINCX 2000). Another possibility of a biological factor would bethedirect regulation of $C$. arenaepopulation through predation by 0 . cobbi. However, this supposition istenuous because at least some other species of Oncholaimus Dujardin, 1845 are not strictly predators (HEIP et al. 1985).

The densities of ovigerous females followed the same pattern as the whole population; i.e., in months of high population densities, ovigerous females were also high. This may occur because eggs are laid only a few days after copulation and an individual reaches sexual maturity a week after hatching from the egg (TIETJEN \& LEE 1972). Because of the relatively long time between each collection, the number of generations of the species could not be defined. However, the density variations suggest that reproduction is continuous throughout the year. Nevertheless, more field and laboratory studies should be done in order to understand better the life cycle of this species at shorter time intervals.

\section{ACKNOWLEDGEMENTS}

The manuscript benefited from the useful comments of Dr. Paulo Santos (Dept. Zoologia/UFPE).

\section{REFERENCES}

ALonGI, D.M. 1990. Community dynamics of free-living nematodes in some tropical mangrove and sandflat habitat. Bulletin of Marine Science, Miami, 46 (2): 358-373.

Amado Filho, G.M.; C.E. Rezende \& L.D. Lacerda. 1999. Poluição da baía de Sepetiba já ameaça outras áreas. Ciência Hoje, Rio de Janeiro, 25: 46-48.

Esteves, A.M. \& V.M.A.P. Silva. 1998. The behavior of sugar flotation techniquein meiofauna extraction from different sandy types. Tropical Ecology, Varanasi, 39 (2): 283-284.

Esteves, A.M.; T.F. Maria, \& A.P. Wandeness. 2003. Population structure of Oncholaimus cobbi (Kreis, 1932) (Nematoda: Oncholaimidae) in a tropical tidalflat. Journal of the Marine Biological Association of the United Kingdom, Cambridge, 83: 903-904.

Heip, C.; M. Vincx; N. Smol \& G. Vranken. 1982. The systematic and ecology of free-living marinenematodes. Helminthological Abstracts, Series B, Farnham Royal, 51: 1-31.

HeIP, C.; M. VINCX \& G. VRankEn. 1985. The ecology of marine nematodes. Oceanography and marine Biology: an Annual Review, Aberdeen, 23: 399-489.

MalakHov, V.V. 1994. Nematodes: structure, development, classification and phylogeny. Washington, D.C., Smithsonian Institution Press, XIII+286p.

M OENS, T. \& M. VInCX. 2000. Temperatureand sal inity contrainst on the life cycle of two brackish-water nematodes species. Journal of experimental marine Biology and Ecology, Amsterdam, 243: 115-135.

MuRPHY, D.G. 1964. Pseudonchus sp. nov. and Comesoma arenae Gerlach 1956: marine nematodes from NSW, Australia. Zoologischer Anzeiger, Jena, 173: 457-432.

Nicholas, W.L. \& M. HoddA. 1999. The freeliving nematodes of temperate, high energy, sandy beach: faunal composition and variation over space and time. Hydrobiologia, Dordrecht, 394: 113-127.

Platt, H.M. \& R.M. WarWick. 1983. Free-living marine nematodes. Part 1: British Enoplids. Cambridge, Cambridge University Press, 307p.

Riemann, F. 1988. Nematoda. p. 293-299. In: R.P. HIGGINS \& H. THIEL (Eds). Introduction to the Study of M eiofauna. Washington, D.C., Smithsonian Institution Press, 487p.

TietJEN, J.H. \& J.J. LeE. 1972. Life cycles of marine nematodes. Oecologia, Berlin, 10: 167-176.

ZAR, J.H. 1996. Biostatistical Analysis. New Jersey, Prentice Hall, $X+662 p$.

Received in 06.V.2004; accepted in 22.IX.2004. 